Journal of Law \& Social Studies (JLSS)

Volume 1, Issue 2, pp 90-98, 2019

www.advancelrf.org

\title{
The Impact of Pharmaceutical Industry on Human Rights
}

\author{
Shagufta Kanwal \\ Judicial Clerk at Supreme Court \\ Email: shaguftakanwal227@gmail.com
}

\begin{abstract}
Pharmaceutical industry and human rights are opposing each other and having conflict at each point relating to access to essential medicine in developing countries. At this point of research some focal points of discord and contestation from the both sectors are tried to explain. The views from pharmaceutical industry can be explained in the form of official's submission during negotiation surrounding the Doha Declaration and the decision that were taken after the Doha Declaration. The industry's views can also be supported by the others who paid their vital role to support the pharmaceutical industries by their writings and morally as well. The main argument given from the pharmaceutical industry was stating that patent is not creating any kind of obstacle creating any obstacle to access essential medicine in developing countries. Actually they try to state that there were health care issues to the citizens of the developing nations before the IP protection is given to the pharmaceutical industries. So, it can be said that the progress in the field of pharmaceutical industry in the developing countries have nothing to do with IP system and the innovation in the pharmacy cannot be achieved by undermining the IP. Most of the problems in the health sector in not related to the patent system in developing countries.
\end{abstract}

Key Words: Pharmaceutical industry, human rights

\section{Introduction}

No doubt patent protection is very important in the pharmaceutical industry to recoup the investment made by the investor and to secure $\mathrm{R} \& \mathrm{D}$ for new drugs but patent protection is not a sole mean to solve the issues in contradiction. Additionally it can be said that patents are just the means not the ends, first and utmost problem for the patent is the restrictions of the competition, for this purpose anti-competition clauses are provided under Competition Act and IP legislation. Generic companies are excluded to serve the industry as a tool in order to increase the price of the medicine thus ultimately poor segment of population cannot access to essential medicine. Another problem sought by the industry regarding stringent patent protection was about the time period of 20 years which allows the patent holders to artificially inflate the prices of the medicines and industries can maximize the revenues which could be seen permissible for developed nations (people having access to essential medicine). But the situation is entirely different in developing world where the prices of the medicines do matter.

It was claimed by the Pogge that when it is allowed to the researcher to make up the investment then it means the prices of the medicine will be higher and would not be affordable for the citizens of the developing world. Muzaka put stress on unjustifiable situation and unethical morally, economically and philosophically to grand the privilege to any individual to harass the market value if they have any invention because according to him their inventions and the protection for the inventions do not guarantee that the society at large would have the access to that particular drug or item. So the people who are living in poverty are not able to afford the high priced medicines and ultimately the infectious diseases proves death sentence for the poor ones while knowing that the disease can be cured but by the high priced medicines which are not able to accessed by them. Economic risks are taken by the poor people to purchase the expensive medicine and in this way they spend their money on medicine instead of food, clothing and education.

Doi.org/10.52279/jlss.01.02.9098 
So World Health Organization contended that every member states should avail the flexibilities which are given under TRIPS to ensure equitable behavior regarding access to essential medicine without any kind of discrimination. It was stipulated by the industries and other human rights proponents that patent protection is not a barrier to access essential medicine and generic competition and small numbers of medicines are patentable according to the World Health Organization's model list. It was further claimed by the industries that the investment on R\&D is three times more than the investment that is made by telecommunications industry, four times more than that of defense industry and any other kind of industries. Hence this argument is concluded in this way that they said research based production of pharmaceutical is much expensive and without this research effective medicines for the infectious diseases cannot be processed or improved.

Apart from everything, pharmaceuticals stimulate $R \& D$ and invention of new drugs and mostly these are directed towards the expensive medicine and profitable for the industry. In this way unprofitable disease are neglected which effect the poor people because they have no more options except buying the expensive medicines in the developing countries and finally so called "global drug gap" exist. World Health Organization noticed that R\&D for pharmaceutical industries is just following the industrialized countries in which the citizens are able to afford the expensive medicine while ignoring the developing part of the world and the crux of the problem can be expressed in the simple words as the disease can be cured by the already existed medicines if these medicines are combined properly and allocated according to the needs of the citizens. Yet no solution was provided for the diseases which are neglected or for which no combined form is effective, in other words tit can be said that the medicines not profitable for the industries.

From the above discussion it can be seen that this battle of argument is endless because it is the matter of perspective. In the developing world patents are utmost importance and considered as vital for the betterment of invention and technology and reforms while in case of developing world the situation is entirely different. The United Nations, World Health Organizations and many other organizations paid their intentions towards TRIPS and subsequent decisions and the dispute can be resolved by the appropriate use of flexibilities that are provided by the TRIPS which is not the exact solution but may be considered as better one for the time being like TRIPS plus, judicial decisions and Free Trade Areas while the situation in developing countries needs the special care and intention to tackle the concerned issue from the international community.

\section{Developing countries and their issues to access essential medicines}

In developing countries the population is increasing each year rapidly and presents approximately $80 \%$ of world population. Two third of the whole population in these countries citizens do not have access to essential medicines. About 10 million people face death punishment just because of these infectious diseases and $90 \%$ of these belong to the developing nations. Because of patent protection high priced medicine is allocated in developing nations along with the pressure from the developed and industrialized countries regarding improving public health and access to essential medicine by providing no help to alleviate the infectious disease.

Legal dispute concerning legislation in the developing and developed countries the pressure is applied on the nonmanufacturing countries like TRIPS plus and FTA's to improve access to essential medicine and empower IP protection. In developing countries the burden of disease is increasing day by day and small amount is invested globally for $\mathrm{R} \& \mathrm{D}$ to cure the disease of poor citizens. It is named as 10/90 gap. There are various barriers to access essential medicine in developing countries like corruption, poverty, unqualified infrastructure for public health and high priced medicine but still patent protection and least investment for R\&D are taken as biggest ones. TRIPS provided the minimum standard for IP protection and developing nation's situation is becoming worst day by day due to this.

Territorial limits are imposed by the TRIPS for compulsory licensing due to which the non-manufacturing countries are unable to import the low priced medicine in their territory to access essential medicine. Crucial developments are tried to make for developing countries in Doha Declaration and subsequent decision to lessen the burden of 
developing countries and to fulfill the basic needs of the nationals. Stress was given in the Geneva Convention regarding the tools that should be adopted by the developing countries so that the rules of World Trade Organization, TRIPS, World Intellectual Property Organization, and Doha Declaration are implemented in the developing countries and the flexibilities provided under TRIPS should be insured to improve the public health. However India affected the developing countries in 2005 by introducing the patents for pharmaceuticals and result the non-availability of low priced version of medicine for the poor nationals.

For developing countries HIV/AIDS is one of the biggest challenges. About 34 million people were having HIV/AIDS in 2011 and 1.7 of them died just because of non-availability of the medicine in the developing countries. Not only lives of the citizens are taken by HIV/AIDS but the development of the countries is also affected by it. It results the poverty in the patients house as they get unable to perform their duties and ultimately their children's cannot get education and standard of living just because of the absence of paternal or maternal support. It is said that about 6 million families are put in poverty due to these disease in 2015. Development is effected due to these infectious diseases as in public sector like agriculture, education and business the non-availability of the labor affects the routine work. Awareness sessions are being organized by the international community, organizations and NGOs in order to address the disease and to get the better solution for developing countries. One of the biggest organization working for this purpose is United Nations Program on HIV/AIDS and known as UNAIDS globally, department of HIV/AIDS under World Health Organization WHO.

There are particularly two more issues for the developing countries that are affecting developing countries namely neglected disease and counterfeit drugs.

\section{Pakistan's experience with pharmaceutical patents: Judicial responses}

Patent litigation is not too wide in Pakistan but some are emerging in this area and this section provides overview of some leading cases in this regard. Section is aimed at elaborating key judicial responses and then attempt has been made to link these judicial interpretations with right to health.

Smith Kline Beecham Corporation and others---Plaintiffs Versus Pharma EVO (PVT.) LTD. ---Defendant

\section{Exclusive market right}

It was observed that Process of manufacturing of medicine which was registered patent in favor of plaintiff and that of the defendant were one and the same. Plaintiff's patent had novelty in use much prior to its registration. Defendant did not disclose its manufacturing process, which gave presumption in favor of plaintiff against defendant. Plaintiff, after chemical trials as was demanded by Government of Pakistan, Health Department, protected their rights pertaining to the process patent registered in Pakistan. Plaintiff had placed on record the process of preparation of the pharmaceutical and had incurred billions of US Dollars upon the invention, process of manufacturing and its marketing. Balance of convenience and irreparable loss was therefore, in favor of plaintiff, if defendant was not restrained from infringing the patent right of plaintiff by marketing the product in question. Presumption of exclusive right of use subsisted in favor of plaintiff as the defendant's rectification obligations were sub judice. Prima facie defendant sought imitation of patent process arisen out of process patent registered in Pakistan. On account of infringement of the patent pieces, plaintiff was entitled to grant of relief of injunction. No controversy existed on the point that defendant's product was registered with Health Department, Government of Pakistan. Question of infringement of patent was altogether a distinct question, which required to be adjudicated under the related law. Plaintiff enjoyed exclusive right of making, selling and using novel invention throughout Pakistan, which had reached the point of turning high business. Balance of convenience and irreparable loss was also in favor of plaintiff. Interim injunction was granted in circumstances.

Right to access essential medicine is a right which is closely connected with right to health. To protect and ensure right to health there is a need to provide the essential medicine without any kind of discrimination and it is the duty of the state to provide the medicine and the arrangements should be medicine a way that the citizens may access to 
medicine. In the above mentioned case one party requires from the other one no to manufacture, import and sale the medicine because the plaintiff has exclusive marketing right over the above said medicine and can only sale the prescribed medicine by clamming the price of its desire. In developing countries like Pakistan the citizens are mostly not able to purchase the high priced medicine and due to this reason the ratio of infectious disease are increasing day by day and affecting the health system of Pakistan.

English Pharmaceutical Industries through Partner and other Petitioners Versus Shire Biochem INC through Authorized Signatory and others---Respondent

\section{To restrain defendant from infringing, counterfeiting and imitating}

It was asserted that under Patent Ordinance, 2000, the term of patent is twenty years and the defendants were producing products containing "LAMIVUDINE" in violation of the patentee rights of the plaintiffs. The case of the defendant on the other hand, was that the plaintiffs' parent Patent bearing No.132128 had already expired and as such no valid patent was presently in existence in favor of the plaintiffs and the other patents were merely patents of addition or improvements of process, they were no more in existence in view of lapse of the above said parent patent and these other patents were not inventions, they lacked novelty and were no more valid patents. Question as to whether plaintiff's subsequent patent, constituted an independent patent being an inventive step rather an improvement or modification of original expired patent, was a master of evidence, which could not be presumed prematurely. Statutory presumption under S.61 (1) (b) of Patents Ordinance, 2000 was available to plaintiff $s$ original patent. Securing the interest of plaintiff would be necessary during the period prima facie; evidence of patent-ability of subsequent patent was brought before court. Defendant tried to establish the origin of its manufacturing process for developing its allegedly infringing product. Plaintiff had failed to make out a prima facie case for interim injunction. Balance of inconvenience was in favor of defendant. Court stopped defendant from supplying infringing drug in market, but allowed him in public interest to supply contract quantity of drug to Government only, but subject to prior furnishing of Bank guarantee in the amount of contract value in favor of plaintiff for its encashment, if tie succeeded in establishing infringement of his patent by defendant. Application for interim injunction was disposed of in such terms.

In the above mentioned case the right to health was in question when the plaintiff claims that the defendant should be refraining from manufacturing the above mentioned drug. The court disposes of the application by granting the favor to defendant and allowing him to sale the medicine for which he has made the contract already in order to fulfill the need of the society. The decision was made in public interest to ensure the public health and right to access essential medicines.

\section{Shire Biochem INC. and others Versus English Pharmaceutical Industries}

\section{Same manufacturing process and expiry of patent protection time period}

In suit for infringement of patent filed by appellant who was a Manufacturer of pharmaceutical product, identical manufacturing process of the product by respondent was challenged. Original patent of appellants had already expired. Notwithstanding the admissions made by the appellants, it was an established fact that they had a process registered under Patent Laws and that the respondent admitted its product to be identical to the appellants' product. Statutory presumpion under S.61 (1) (b) of the Patents Ordinance, 2000, was attracted to the facts of the case. Statutory presumption under S.61 (1) (b) of the Ordinance was available to the appellants' patent, and therefore, it was necessary that the

interests of the appellants be duly secured during the period that prima facie evidence on its patentability was brought before the Trial Court to explain and displace' the admissions of the appellants brought on record. Such reasoning would not support the grant of interim injunction to the appellants at the present stage (first appeal from order), however, that could not authorize the respondent to manufacture and sell its product without establishing the originality of its manufacturing process and, ' thus, its bona fides. 
Respondent, to exonerate itself from the burden of the statutory presumption, must disclose and establish its process for developing its allegedly infringing product, which could be established by the process of reverse chemical analysis of the respondent's allegedly infringing product, wherefrom a fairly accurate picture about the process employed by the respondent could be obtained. Two facts namely, expiry of original patent of the appellants and the statement that the product of the expired patent was the active ingredients of the appellants' product had diminished the appellants' prima facie case for an immediate injunctive order. Refusal to issue injunctive order was also justified for a very weighty reason that was the plea of public interest adopted by the respondent which tilted the balance of convenience in favor of respondent, as respondent had stated that a public tender calling for medicine treating Hepatitis-B was floated by Prime Minister Program, respondent being the lowest bidder of an approved drug was declared the successful bidder and a contract of 365000 tablets of the medicine within 35 days was awarded to the respondent. High Court, in the interest of justice and in furtherance of the object of Patents Ordinance, 2000, directed that the product of the respondent shall be tested and analyzed by a competent international laboratory with prior notice to and upon the criteria notified by the appellants; test and analysis shall be conducted forthwith and their result shall be provided to the parties within one month of the date of present judgment.

If the result showed manufacturing process identical to that of the appellants, the latter shall have the right to move a fresh application for interim injunction before the Trial Court which shall be decided on merits and material on record at that time. Counsel for the parties objected on nationalistic considerations to the tests being conducted by laboratories in the jurisdiction of domicile of either of the parties or in Pakistan-High Court, to promote credibility of the test reports, ordered that a laboratory in Malaysia or Singapore, neither country having any connection with the parties to the suit, shall conduct and report on the relevant tests of the respondent's product. National Public Health Laboratory of Malaysia at Selangor was designated in the first instance, to conduct the necessary tests. If the said laboratory declined or was otherwise unable to conduct the said tests and analysis, the Trial Court shall, with the consultation of the counsel for the parties order for another laboratory to conduct the requisite tests and analysis, and shall treat the time to be of the essence. On the touchstone of public interest arising on account of the medical emergency in the country as well as the expiry of the appellant's original patent, balance of convenience was found by the High Court to be in favor of the respondent. High Court, therefore, ordered that the respondent shall supply the contract quality of its product to the Prime Minister Program and in doing so; however, the respondent shall not supply its product either in the market or to any other person.

On account of the fact that the respondent shall be deriving advantage from a commercial bargain that derogated alleged patent rights of the appellants, it was further directed by the High Court that prior to making supply of medicine to the Prime. Minister Program the respondent shall submit in the Trial Court a Bank guarantee of a Scheduled Commercial Bank in the amount of the respondent's contract value supplied to the Program, issued in favor of the appellants for its encashment by appellants if they succeed in establishing before the competent Court their case of infringement of their patent by the respondent.

To access the essential medicine is one of the fundamental right of the citizens of state but when the pharmaceutical companies tries to grab the rights of citizens in form of taking patent protection and hence in this way high priced medicine are sold in market and poor citizens of developing countries like Pakistan are restrained to cure their diseases. The above mentioned case is about the manufacturing process where the another pharmaceutical company just because of same manufacturing process and selling the particular medicine in low price under prime minister scheme to fulfill the needs of the society to cure the disease and meet the highest attainable standard for health. The decision was made in public interest where the respondent was allowed to provide the medicine ordered under Prime Minister Scheme so that the government takes part to improve the public health.

Glaxo Group Limited and others Versus Evron (private) limited and others

\section{Overseas manufacturing of identical product and importing in Pakistan}


Plaintiff filed suit for interim Injunctions against defendant. The Division Bench of Karachi High Court accepted the appeal filed by Glaxo and granted an interim injunction against Evron in a case where Evron was importing a drug by the name of 'Malfax' containing rantidine from Canada during the validity of Galxo's process patent for preparing rantidine in Pakistan. It was held that "If a person, in making a product overseas uses processes which would be infringing processes here, those processes being a principal part of the manufacture and then imports the article into this country, he is guilty of an infringement. The reason is because, by using those processes overseas and bringing the product here to sell, he deprives the Pakistani Patentee of the benefit of the invention.

Here in the above mentioned case, as far as the right to life and access to essential medicine is concerned, flexibility is provided under TRIPS by means of compulsory licensing. In case the home industries are not able to manufacture the product to fulfill the need of society then the government may with or without the permission of the concerned parent pharmaceutical industry order to manufacture the drug and then can import it to its territory to secure and protect the right to life of the citizens. But when the other state's pharmaceutical industries tries to infringe the right of the actual holder by manufacturing the same product without the permission, the government should take the immediate and proper steps to stop the violation and arrange another suitable way to attain highest attainable standard for health in the country instead of violating patent holder right. It can be done by adopting the flexibility given under TRIPS that is Compulsory licensing.

Sandoz limited Versus Pakistan Pharmaceutical Products Limited

\section{Matter of piracy}

Application for an injunction to restrain defendant until further order, for manufacturing, importing, marketing selling or offering for sale the product which infringe the plaintiff's patent. Expert opinion held that by reading the description on defendant's packets and impression is created that the base of defendant drug was similar to the drug which is associated with the name of plaintiff as their exclusive product and which had by now earned a worldwide reputation. Infringement of patent so obvious that plaintiff had been able to make out a strong prima facie case in their favor. No plausible explanation offered by defendant for using the name of patent of plaintiff. It was held in case where no plausible explanation was forthcoming, the mischief should be suppresses as early as possible and the piracy causing financial loses to the plaintiff and health hazard to the public at large which remained unexplained should not be allowed to continued. Mere registration of drug with ministry of health under drugs act, 1976 could not immunize the defendant against claims of aggrieved party under the patent and design act, 1911-defendant was restrained from importing, marketing or publicizing any product under the name of plaintiff or reproducing the chemical or structural formula of the said drug on any of their products in any form.

To secure and protect the right to health, the state should take the appropriate and immediate step towards the piracy and the drugs which are causing damage to public health and do not meet the standard fixed by the health ministry. In this way the government may protect the right of the patent holder and the right to health as well. In the above mentioned case the same scenario is given where one of the party committed piracy and the drugs prepared by that pharmaceutical company was causing adverse effect hence was refrained to manufacture and sell the drugs in the market.

Messrs Getz Pharma (PVT) LTD. through Authorized Person Versus Federation of Pakistan, through Secretary, Ministry of National Regulation and Services and another

\section{Fixation of price of life saving drug}

The instant petition relates to the breakthrough medicine generically known as Sofosbuvir which is termed as a miracle medicine taken orally for the cure of Hepatitis-C, of which there are more than 13 Million sufferers in Pakistan making Pakistan rank as No.2 country in the world on account of prevalence of this deadly disease. Dispute was with regard to fixation of price of life saving drug meant to cure Hepatitis-C. Petitioner was aggrieved of fixation of too low retail price of medicine in question by authorities. It was observed and held by the court that 
Where drug was intended to heal a large part of population of Pakistan suffering from Hepatitis-C (4.5\% of population), in public interest (even if patent was granted), Federal Government had ample power to invoke S.58 of Patents Ordinance 2000 to grant compulsory licenses to local pharmaceutical companies to produce drug in question at cheaper rates. High Court directed the authorities to recognize and take steps to show that they had recognized that 'access to affordable medicine' was a fundamental right granted and protected under Arts.9 \& 14 of the Constitution. Authorities were directed that "Maximum Retail Price" for essential drugs not to be set unless flexibilities provided under S. 58 of Patents Ordinance 2001, had been fully exhausted in a transparent manner.

High Court declared that fixing Maximum Retail Price of medicine in question, as appropriate procedure of price determination of the compound in neighboring countries was complied with and Federal Government had residual authority to issue the notification in partial modification of Cl.4(4)(i) of Drug Pricing Mechanism. High Court also directed the authorities to adopt due process provided under Drug Pricing Mechanism and after giving opportunity of hearing, re-fix Maximum Retail Price of drug in question strictly in accordance with law. Constitutional petition was dismissed in circumstances.

In the above mentioned case the scope of right to health is elaborated through Drugs Regulatory Authority of Pakistan act 2012. As the state has the responsibility to maintain the highest attainable standard of health. In this regard the court stated that federal government has the power to grant compulsory license with or without the permission of the patent to manufacture the drugs as done in the above mentioned case to cure the infectious disease named Hepatitis.

\section{Smith Kline and French Laboratories Limit versus Ferozsons Laboratories Limited}

Plaintiff had filed the suit for infringement of patent against the plaintiff. Smith Kline had valid patent for the manufacture of the drug thus defendant didn't register his drug under the patent Act \& also used the same process of manufacturing the drugs under which the plaintiff's company is manufacturing. Plaintiff claimed for damages. The defendants have not produced any evidence to indicate that their drug has been produced by a process other than the process for which the plaintiffs hold the patent. The court granted the relief as claimed for along with damages and other restraining orders. This is yet another example of the fact that the courts in Pakistan are not hesitant in granting full protection to intellectual property rights. Other patent cases advancing the law on similar lines and decided by our courts have been reported in 1987 CLC 1571 and 1992 CLC 2382.

\section{Conclusion and Recommendations}

Extensive literature and recommendations are circulating at international level but yet there is no suitable solution is given that may be acceptable by both the sectors; pharmaceutical industry and human rights. Efforts are made by numerous sectors to find the solution but the success can only be tasted when governments would take necessary measures in this regard. High cooperation is needed from World Trade Organization, other international organizations and pharmaceutical industries to uphold the better solution of the concerned problem.

If we look the TRIPS agreement with great care then it can be seen that is bringing the huge modifications with regard to intellectual property rights for the developed countries only and the process of innovation is down streaming for the developing world. Obligations are imposed on all the member states to grant the patent protection on all the forms of technologies, in this sense it is preventing the developing countries to decide the strategy through which the developing world may get the highest benefit for their development.

Pogge has stated that we can idealize the world where everyone is enough rich to afford the medicine upon the prices fixed by the pharmaceutical industry or need the medicine only after the expiry of patent protection time period. In this way the patent protection will be acceptable by the human rights critique and the protection will bring the prosperity for the innovative world. Right to the highest attainable standard of health is closely connected to all other fundamental human right irrespective of social, economic, Civil and political rights of the citizens. 
In the absence of good health no one can be able to enjoy the life with full extent. Right to access to essential medicine is indispensable with the right to health and forms the part of international customary law. Regardless of the place of residence and their financial position every citizen around the globe must have the access to essential medicine of good quality. States should make it happened by providing the medicine at lower and cheaper rates. Pharmaceutical industries are busy to get their profit after investing on R\&D by letting the people on bed of death in least-developed and developing countries.

Presentment situation can perfectly be expressed by the following line of Oscar Wilde "Nowadays people know the price of everything and the value of nothing". It is already mentioned that the disease which are affecting developing part of the world would affect the citizens of developed countries within no time. In order to avoid the situation the pharmaceutical industry has to choose the better option among public health and their profit against investment.

HIV/AIDS pandemic and the response of international community towards this is a great gesture to improve the situation of right to health and access to essential medicine without any kind of information. International community can do a great job to improve the public health in developing countries. According to my opinion, the reward to pharmaceutical companies in the form of fund that bring the positive attitude towards public health and effective drugs for infectious disease, may be a best solution of the problem. Global drug gap should be eliminated to resolve this particular conflict.

Compromises should be made by both the parties to resolve the conflict that might not be ideal for them. Until and unless the basic difference between these two sectors would not be dissolved the desired results cannot be achieved. Consensual approach should be made towards the conflict of pharmaceutical industry and human right to make the way for the citizens to enjoy their life with full zeal and zest while on the other side the industry may make the profit for their investment. Access to medicines can ever be obtained by only removing the barriers of patent barriers but the need of proper funding for health care system, good quality of medicine, corruption free schemes and wise selection of drugs is necessary.

\section{References}

1987 CLC 1571 Karachi

1992 CLC 2382 (Karachi)

1992 MLD 2226

2006 CLD 1038 [Lahore]

2006 CLD 716

2007 CLD 1570

Abbott et al, "The WTO Medicines Decision: World Pharmaceutical Trade and Protection of Public Health", (2005) 99 American Journal of International Law at 317.

Austin and Helfer, "Human Rights and Intellectual Property: Conflict or co-existence?" (2004).

CIPIH Report 2006, p. 10

F. Rozanski, "Developing Countries and Pharmaceutical Intellectual Property Rights: Myths and Reality" (2007), Stockholm Network, p. 4

Geneva Declaration on the Future of WIPO, (2004) available at: http://www.cptech.org/ip/wipo/futureofwipodeclaration.pdf,

Helfer and Austin, "Human rights and intellectual property: mapping the global interface", (2011) Cambridge University Press. 92 
Helfer and Austin, "Human rights and intellectual property: mapping the global interface", (2011) Cambridge University Press. 40, 124-5.

Joseph, Sarah, “Trade and the Right to Health”, 2009.

Muzaka, Valbona, "The Politics of Intellectual Property Law and Access to Medicines", (2011) International Political Economy Series, Palgrave Macmillan, p. 23.

O. Wilde, The picture of Dorian Gray (1890) e-book available at: http://www.gutenberg.org/files/174/174h/174h.htm, Chapter 4.

PLD 2017 Sindh 157

Pogge et al. (eds.), "Incentives for Global Health: Patent Law and Access to Essential Medicine”, (2010) Cambridge University Press, p.4.

Pogge, Thomas, “Could Globalization be good for World Health?” (2007) Global Justice: Theory practice Rhetoric. Report of the High Commissioner for Human Rights, Para. 45.

T. Pogge, "Could Globalization be good for World Health?" (2007), Global Justice: Theory practice Rhetoric, p.1. UN Millennium Project 2005, p. 137.

WHO Drug Information, p. 218. 